\title{
Hydrothermal plume mapping as a prospecting tool for seafloor sulfide deposits: a case study at the Zouyu-1 and Zouyu-2 hydrothermal fields in the southern Mid-Atlantic Ridge
}

\author{
Chunhui Tao ${ }^{1,2}(\mathbb{D}) \cdot$ Sheng Chen ${ }^{1,2} \cdot$ Edward T. Baker ${ }^{3} \cdot$ Huaiming $\mathrm{Li}^{2} \cdot$ \\ Jin Liang ${ }^{2}$ Shili Liao ${ }^{2} \cdot$ Yongshun John Chen ${ }^{4}$ Xianming Deng ${ }^{2}$. \\ Guoyin Zhang ${ }^{2} \cdot$ Chunhua $\mathrm{Gu}^{2} \cdot$ Jialin $\mathrm{Wu}^{2}$
}

Received: 20 April 2016/Accepted: 26 May 2016/Published online: 6 June 2016

(c) The Author(s) 2016. This article is published with open access at Springerlink.com

\begin{abstract}
Seafloor hydrothermal polymetallic sulfide deposits are a new type of resource, with great potential economic value and good prospect development. This paper discusses turbidity, oxidation-reduction potential, and temperature anomalies of hydrothermal plumes from the Zouyu-1 and Zouyu-2 hydrothermal fields on the southern Mid-Atlantic Ridge. We use the known location of these vent fields and plume data collected in multiple years $(2009,2011,2013)$ to demonstrate how real-time plume exploration can be used to locate active vent fields, and thus associated sulfide deposits. Turbidity anomalies can be detected $10 \mathrm{~s}$ of $\mathrm{km}$ from an active source, but the location precision is no better than a few kilometers because fine-grained particles are quasi-conservative over periods of many days. Temperature and oxidation-reduction potential anomalies provide location precision of a few hundred meters. Temperature anomalies are generally weak and difficult to reliably detect, except by chance encounters of a buoyant plume. Oxidation-reduction potential is highly sensitive (nmol concentrations of reduced hydrothermal chemicals) to discharges of all temperatures and responds immediately to a plume
\end{abstract}

Sheng Chen

chensheng1988@126.com

1 College of GeoExploration Science and Technology, Jilin University, Changchun 130026, China

2 The Second Institute of Oceanography, State Oceanic Administration, Hangzhou 310012, China

3 Joint Institute for the Study of the Atmosphere and OceanPMEL, University of Washington, Seattle, WA, USA

4 Department of marine science and engineering, South University of Science and Technology of China, Shenzhen 518055, China encounter. Real-time surveys using continuous tows of turbidity and oxidation-reduction potential sensors offer the most efficient and precise surface ship exploration presently possible.

Keywords Sulfide-prospecting criteria $\cdot$ Hydrothermal plume dispersion · Mid-Atlantic Ridge

\section{Introduction}

Most hydrothermal fields are found on mid-ocean ridges (Beaulieu et al. 2015). Slow-spreading mid-ocean ridges account for $60 \%$ of the $64,000 \mathrm{~km}$ total length of global mid-ocean ridges. It is estimated that about $85 \%$ of midocean ridge sulfide deposits occur on slow-spreading ridges (Hannington et al. 2011). The shape, type, and size of midocean ridge polymetallic sulfide deposits are controlled by complex geological factors, such as local magma supply, crustal permeability, tectonics, and magmatism (e.g., Devey et al. 2010). Currently, the investigation of seafloor hydrothermal systems is still in the scientific research stage. With progress in deep-sea survey technology and depletion of mineral resources on land, the development of seabed mineral resources has become a research objective for countries around the world. Since 2011, surveys of seafloor polymetallic sulfide resources by nations and corporations have progressed to an exploratory stage (Nautilus Minerals Inc. 2014).

An important aspect of this exploration is development of realistic survey protocols for determining the location of active hydrothermal sites. Active hydrothermal sites have been confirmed by seafloor observations or inferred by water column measurements in every ocean and at all spreading rates, which gives us a wealth of hydrothermal 
data to study the hydrothermal plume ore-prospecting criteria. Ore-prospecting criteria for polymetallic sulfide deposits have been proposed by studying geology, topography, water mass characteristics, mineralogical and geochemical characteristics of nearby sediments, geophysical characteristics, and living organisms (Yao et al. 2011; Fang et al. 2015; Shao et al. 2015). However, these papers focus on seafloor criteria and do not describe how hydrothermal plume studies can be used to locate seafloor vent sites.

Because of the present difficulty in locating inactive deposits, exploration has focused on the detection of active sites, followed by a search for nearby inactive sulfide fields (Tao et al. 2014; German et al. 2016). Since the discovery of the Trans-Atlantic Geotraverse (TAG) hydrothermal vent, located at $26^{\circ} \mathrm{N}$ in the Mid-Atlantic Ridge (MAR) (Rona et al. 1986), studies of active seafloor vent sites in the slow-spreading MAR have increased, as they are a key area in the investigation and study of submarine hydrothermal sulfides (Rona et al. 2010). Other hydrothermal fields in the northern MAR from $12^{\circ} \mathrm{N}$ to $40^{\circ} \mathrm{N}$ include Logatchev, Snake Pit, Broken Spur, Rainbow, Lucky Strike, Menez-Gwen and Ashaze (Murton et al. 1994; Krasnov et al. 1995; German et al. 1996; Langmuir et al. 1997; Charlou et al. 1988; Sudarikov and Roumiantsev 2000). Fewer active hydrothermal sites have been confirmed in the southern MAR. Before 2009, only five hydrothermal fields were known on the southern MAR, all located between the equator and $10^{\circ} \mathrm{S}$ near Ascension Island (Fig. 1) (Devey et al. 2005; Melchert et al. 2006; Haase et al. 2007; German et al. 2008; Keir et al. 2008; Melchert et al. 2008; Haase et al. 2009, 2012).

Hydrothermal plumes, formed by the turbulent mixing of hot vent fluids and ambient seawater, are potent tools for locating, characterizing, and quantifying seafloor hydrothermal discharge. The emitted fluids rise by the buoyancy of the hot hydrothermal fluids and are gradually diluted by seawater, ascending until the plume becomes non-buoyant. Hydrothermal plumes can then spread laterally over distances of a few kilometers to more than $1000 \mathrm{~s}$ of km (e.g., Baker et al. 1995; Lupton and Craig 1981; Saito et al. 2013; Resing et al. 2015). Hydrothermal plumes are rapidly diluted $\sim 10^{4}$-fold with ambient seawater, yet retain physical and chemical signatures distinctly different from background seawater (Speer and Rona 1989; Mottl and McConachy 1990). Hydrothermal plume parameters can be divided into three aspects: physical characteristics (temperature, turbidity), chemical characteristics (e.g., gases such as ${ }^{3} \mathrm{He}, \mathrm{H}_{2}, \mathrm{CO}_{2}, \mathrm{CH}_{4}, \mathrm{H}_{2} \mathrm{~S}$; metallic elements such as $\mathrm{Fe}$ and $\mathrm{Mn}$ ), and movement characteristics (rise height, advection of the non-buoyant layer) (Tivey 2007). The characteristics of hydrothermal plumes are closely associated with the characteristics of hydrothermal fields. Movement characteristics are related directly to the
Fig. 1 Bathymetry and location of the spreading axis between the equator and $16^{\circ} \mathrm{S}$ in the Atlantic Ocean. Also shown are the segment names used in this paper. Red stars mark discovered hydrothermal sites. Map created with GeoMapApp (http://www.geomapapp.org; (Ryan et al. 2009). Most bathymetric information is from satellite altimetry data with high-resolution information from the LamontDoherty Earth Observatory marine geophysics data (Smith and Sandwell 1997)

buoyancy flux and the local currents (Rudnicki and Elderfield 1992). Ore-prospecting criteria for seafloor polymetallic sulfide deposits include hydrothermal plume characteristics that can be used as clues during prospecting. The extent of hydrothermal plumes is much greater than that of sulfide deposits and more easily detected, enabling the effective and fast location of seafloor hydrothermal vents and potential seafloor polymetallic sulfide deposits.

This paper uses recent water column studies in a southern MAR tectonic segment to show how real-time measurements of hydrothermal plume tracers (turbidity, oxidation-reduction potential (ORP), and temperature) can be used to precisely locate active vent sites and, thus, the possibility of nearby sulfide deposits.

\section{Geologic background}

For this paper, we numbered ridge segments between the equator and $16^{\circ} \mathrm{S}$ in the southern MAR (Fig. 1). The study area is located on a first-order ridge segment, which is separated by the Bode Verde II transform fault in the north and the Cardno fracture zone in the south, with a full spreading rate of $34 \mathrm{~mm} / \mathrm{yr}$ (DeMets et al. 1994). A distinct second-order non-transform discontinuity (Macdonald 2001) at $13.5^{\circ} \mathrm{S}$ offsets the $13^{\circ} \mathrm{S}$ to $14^{\circ} \mathrm{S}$ ridge segment into two minor sections, labeled S14 and S15 (Fig. 1).

The Zouyu-1 (former name: Valentine Valley) and Zouyu-2 (former name: Baily's Beads) hydrothermal fields (Fig. 2) are located on the neovolcanic Zouyu ridge on the axis of a symmetrical spreading ridge (on the eastern side of the S14 segment) (Tao et al. 2011). The Zouyu ridge is $>1 \mathrm{~km}$ shallower than the deepest part of the segment. The combination of magmatism and tectonic activities leads to the evolution of high-temperature hydrothermal venting at the ridge axis, which results in favorable conditions for large-scale polymetallic sulfide deposits.

The Zouyu-1 hydrothermal field $\left(14.41^{\circ} \mathrm{W}, 13.25^{\circ} \mathrm{S}\right)$ was discovered during Chinese 22nd cruise (Table 1) (Fig. 3). A sulfide chimney and a large area of altered basalt nearby were video recorded by underwater camera at a depth of $2315 \mathrm{~m}$. About $4 \mathrm{~km}$ south, the Zouyu-2 field $\left(14.41^{\circ} \mathrm{W}, 13.28^{\circ} \mathrm{S}\right)$, at a depth of $2288 \mathrm{~m}$, was discovered during Chinese 21st cruise (Table 1). Hydrothermal 


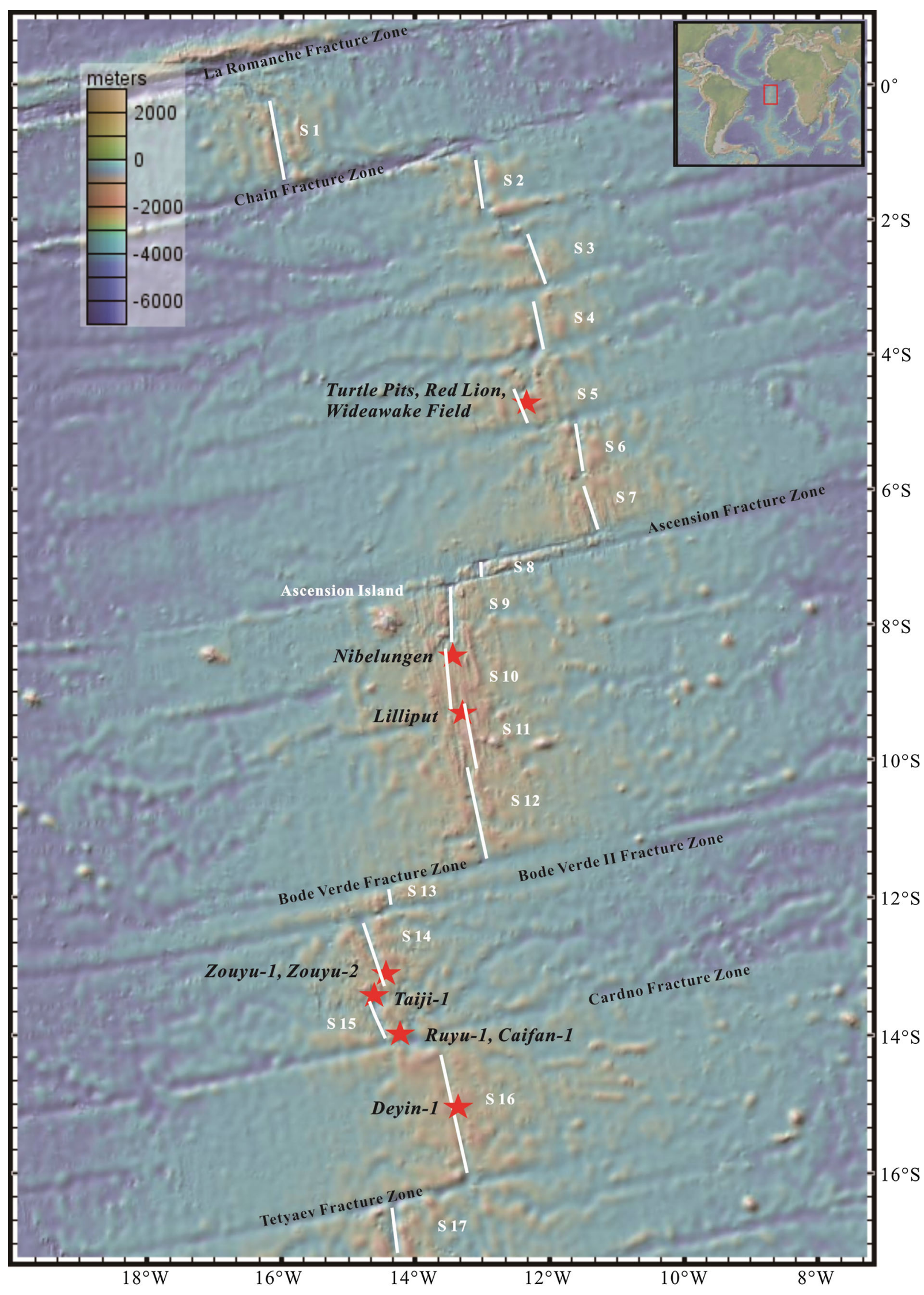


anomalies were detected using deep-tow MAPRs (Miniature Autonomous Plume Recorder) and ECS (electrochemical sensor) hydrothermal detecting equipment. Black smokers, polymetallic sulfides, altered basalts, and diffuse venting were video recorded by underwater camera. Polymetallic sulfide samples were acquired by TVG (TV grab). These data provided the first evidence for the position of new hydrothermal vents. Sidescan sonar imagery acquired during the German MSM25 Cruise in 2013 (Devey 2014) showed evidence of several sulfide structures (chimneys and mounds). The brightest backscatter was seen in the rift boundary, west of the hydrothermal field, suggesting this was the location of the most recent volcanism (Devey 2014).

During our surveys, the fractures in the study area were found to be shallow and narrow, and mostly $\mathrm{N}-\mathrm{S}$ oriented (Tao et al. 2011). Rocks in the study area were mainly basalt, with different characteristics in different areas. Four types of basalt were identified: pillow basalt, large breccia, rubble breccia, and hydrothermally altered rocks. Rubble breccia and sediment were distributed evenly around the area. Hydrothermally altered rocks were mainly distributed near the vent. The geological settings of the Zouyu-1 and Zouyu-2 hydrothermal fields are similar to those in the Snake Pit and Turtle Pits (Devey et al. 2010). All of these areas feature basalt basement, so an along-axis magma chamber likely provides the heat for these vents. Faults in the volcanic area, magma channels below the deep volcano, and fissures caused by cooling volcanic rock would provide channels for seawater infiltration and hydrothermal fluid discharge, promoting the development of large-scale polymetallic sulfide deposits.

\section{Data collection and processing}

Data presented here were acquired during two cruises on the southern Mid-Atlantic Ridge (Table 1). During the 21IV leg in 2009 and the 22II leg in 2011, plume surveys were conducted on the Zouyu Ridge using a towed instrument package equipped with light-scattering and temperature sensors (MAPR), and $\mathrm{H}_{2} \mathrm{~S}$ and ORP sensors (ECS) (Tao et al. 2011). The ECS, which is made by Zhejiang University, integrates three types of electrochemical electrodes, including $\mathrm{ORP}, \mathrm{H}_{2} \mathrm{~S}$ and $\mathrm{pH}$ electrodes, and can detect concentration changes of ORP, $\mathrm{H}_{2} \mathrm{~S}$ and $\mathrm{pH}$ in water column caused by active hydrothermal venting, and even weak chemical abnormalities by nonactive massive sulfide hydrothermal mound which MAPR and CTD generally cannot detect (Han et al. 2015). The towed package was located using ultra-short baseline (USBL) positioning relative to the ship, which was located using differential global positioning system.
Fig. 2 Bathymetry of the study area $13^{\circ} \mathrm{S}-14^{\circ} \mathrm{S}$ collected by the multibeam sounding system during cruises 21IV and 22II. Also shown are the positions of active hydrothermal fields (red stars) and hydrothermal anomalies (red solid circles) (Tao et al. 2011). The white solid lines represent second-order ridge segments

A series of MAPRs were connected at set intervals along a cable, forming a $300-500 \mathrm{~m}$ vertical MAPR array to cover the scope of a hydrothermal plume. The array provides rapid detection of plumes in situ by measuring multilayered information in the lateral and vertical directions, including turbidity, temperature, and ORP. The survey is conducted at a relatively high speed $(2 \mathrm{kts})$, improving the efficiency of investigations. MAPRs can be attached to cables, CTD casts, or TVG casts to acquire small-scale vertical turbidity profiles. A series of processing steps was applied to the turbidity data, including correction for position deviation, data de-noising, and systematic error correction (Chen et al. 2014). During the 21IV leg, we focused four towing profiles and four vertical profiles (TVG stations) on the region. The 21IV-L04 and 21IV-L08 survey lines were in NE-SW direction and went through the Zouyu-2 hydrothermal field. During the 22II leg, data were collected from four towing profiles, two TVG stations, and five CTD casts (Fig. 3). Two lines are worth noting. The 22II-L09 survey line ran in NW-SE direction from the Zouyu-1 hydrothermal field to the Zouyu-2 hydrothermal field and the 22II-L07 survey line ran through the Zouyu-2 hydrothermal field in E-W direction (Fig. 3).

Additional data in our study area were acquired during the German MSM25 voyage in 2013. Summaries of this work are available in a Cruise Report (Devey 2014). Their work included deep-tow lines and use of an autonomous underwater vehicle (AUV) for near-bottom mapping and hydrothermal plume detection. Two tow-yo survey lines were conducted around the Zouyu-2 hydrothermal field (Fig. 3). The Tow-yo_2 survey line runs North-South from the Zouyu-1 hydrothermal field to the Zouyu-2 hydrothermal field, approximately paralleling to the line 22II-L9. An AUV mission using ORP and turbidity sensors was conducted at an altitude of $40 \mathrm{~m}$ over areas of the known Zouyu-1 and Zouyu-2 hydrothermal fields.

\section{Characteristics of hydrothermal plumes}

\section{Turbidity anomalies}

\section{Distribution of turbidity anomalies}

The areal extent of turbidity anomalies around Zouyu-1 and Zouyu-2 in 2009 and 2011 shows that the highest 

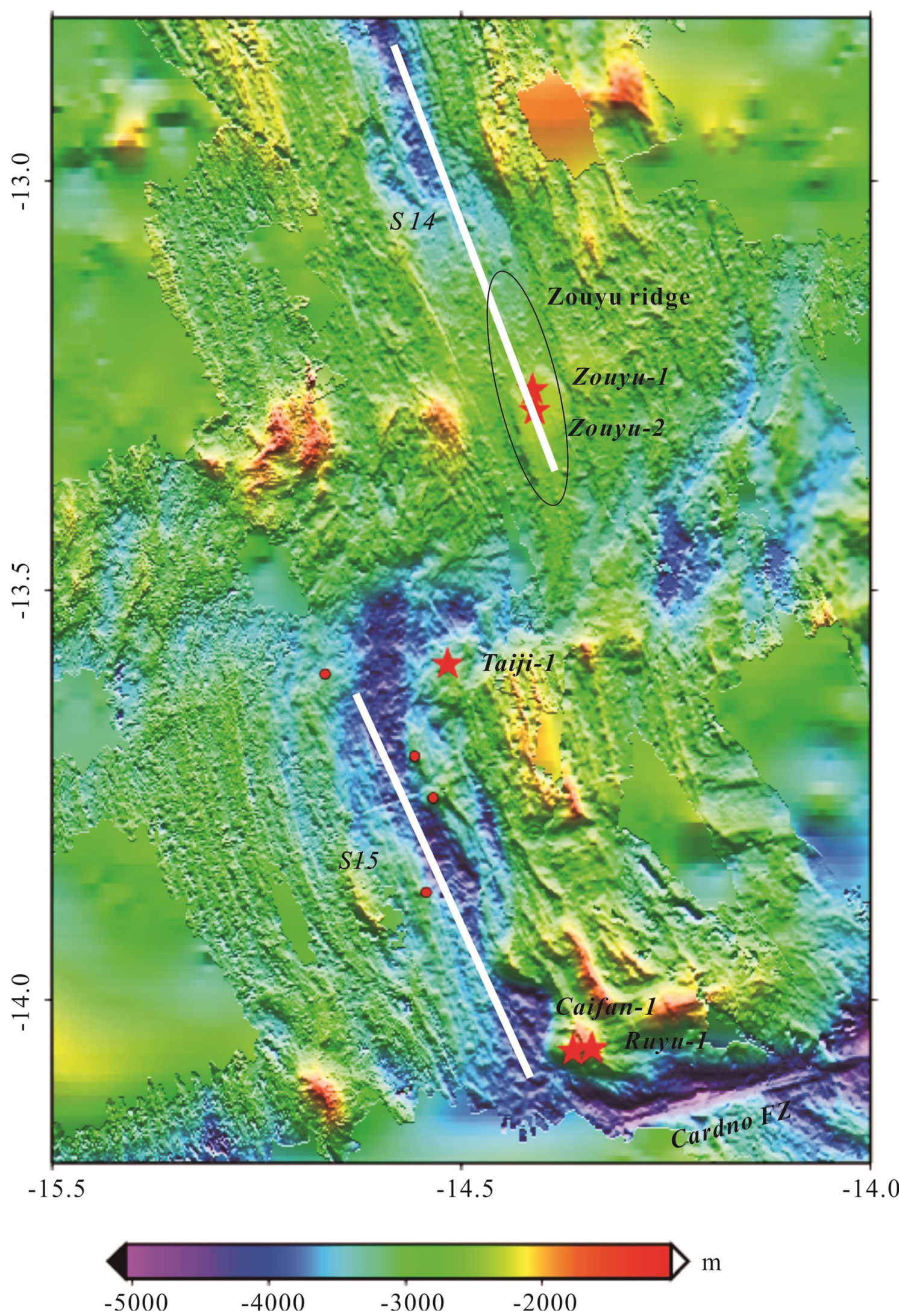
values were concentrated around Zouyu-2 (Fig. 4). The turbidity anomalies were widely distributed, with a maximum anomaly value of $0.094 \Delta \mathrm{NTU}$ (Nephelometric Turbidity Units) southeast of the Zouyu-2 vent. The turbidity values around Zouyu- 1 were lower. The locations of high turbidity values do not correlate exactly with the positions of Zouyu-2 hydrothermal vents (Fig. 4), with the position deviation of $0.85 \mathrm{~km}$. The MSM25 AUV over the Zouyu Ridge found a distribution of turbidity values similar to our data collected in 2009 and 2011 (Devey 2014).

The most distinct turbidity anomalies were observed on survey lines 21IV-L04 and L08 in the Zouyu-2 hydrothermal field (Fig. 5a). This transect showed a concentrated plume layer at depths between 2050 and $2250 \mathrm{~m}$, with a maximum turbidity anomaly of $0.08 \Delta \mathrm{NTU}$ at a depth of $2120 \mathrm{~m}$. The horizontal scale of hydrothermal plume maximum was $\sim 2.5 \mathrm{~km}$. The plume maximum is offset $\sim 500$ m east of the Zouyu-2 vent location. Such an offset is not unlikely given the constant advection of plumes by local tidal currents. Examples include a multiyear time series of plumes over the Cleft segment of the Juan de Fuca Ridge (Baker 1994) and a 24 h time series at a single location over a vent field on the Central Indian Ridge (Rudnicki and Germa 2002).

The 22II-L09 survey line in 2011 showed a plume detectable at least $3 \mathrm{~km}$ to the north of Zouyu-2, but more than $100 \mathrm{~m}$ deeper than seen in 2009 (Fig. 5b). The range of turbidity anomaly values detected in the Zouyu-2 hydrothermal field is $0.018-0.035 \Delta \mathrm{NTU}$, values much less than that on the line 21IV-L04. The plume maximum was located directly above the Zouyu-2 vent field, and also coincident with an ORP anomaly and buoyant plume detected during the MSM25 AUV dive (Devey 2014). The lateral scale of the plume maxima during 22II-L09 was $\sim 1 \mathrm{~km}$, much less than on line 21IV-L04 and L08.

In 2013, results from the MSM25 cruise showed that the depth of the plume maxima was again $\sim 2125 \mathrm{~m}$, similar to that found in 2009, and maximum turbidity values exceed 0.1 NTU (Devey 2014). The remarkable difference between 2009/2013 and 2011 could arise from stronger currents in 2011 bending the plume and injecting it deeper into the water column (Rudnicki and Germa 2002) but unless such currents were steady over many days plumes would be visible over a depth range of several hundred meters. Because of the weak turbidity values and greater plume depth in 2011, a more likely explanation is that 2011 was a period of reduced buoyancy flux.
Fig. 3 Distribution of stations and survey lines near the Zouyu ridge. Solid symbols indicate station measurements made during the 21IV leg, while open symbols indicate measurements made during the 22II leg. Red stars represent hydrothermal vents. White dotted and dashed surveying lines were made during the German MSM25 cruise, while the dotted rectangle shows the German AUV \#135 dive area. Black lines for 21IV leg survey lines, and red lines for 22II leg lines

\section{Dispersion trends of turbidity anomalies}

Vertical casts at stations $0.5 \mathrm{~km}$ (21IV-TVG02), $1 \mathrm{~km}$ (21IV-TVG04), and $3.5 \mathrm{~km}$ (21IV-TVG03) northwest of the Zouyu-2 (Fig. 6) found hydrothermal plumes between 2050 and $2300 \mathrm{~m}$, consistent with depths on the 21IV-L04 and L08 transect. The turbidity at 2120 showed an obvious decreasing trend away from Zouyu-2, with maximum values of $0.04 \Delta \mathrm{NTU}, 0.03 \Delta \mathrm{NTU}$, and $0.02 \Delta \mathrm{NTU}$, respectively. The lateral scale of this plume detection is thus similar to that seen on the 21IV-L04/21IV-L08 transect (Fig. 5).

Near the Zouyu-1 hydrothermal field, stations 22IITVG12, 22II-CTD08, 22II-CTD11, and 21IV-TVG05 are located northwest of the vent, at distances of $0.28,0.93,2.17$, and $3.77 \mathrm{~km}$, respectively (Fig. 6c). Turbidity decreased with dispersion of the non-buoyant layer and returned to the background value at a distance of $\sim 2.2 \mathrm{~km}$.

\section{ORP anomalies}

ORP anomalies were detected near Zouyu- 2 in 2011. On survey line 22II-L07 sharp and substantial ORP $(\sim 80 \mathrm{mV})$ and $\mathrm{H}_{2} \mathrm{~S}(2.5 \mathrm{nmol} / \mathrm{L})$ anomalies occurred near $14.412^{\circ} \mathrm{W}$, $13.28^{\circ} \mathrm{S}$ for $\sim 300 \mathrm{~m}$ along the track line (Fig. 7). Similar anomalies were detected by the MSM25 AUV dive in 2013 (Devey 2014). Strong turbidity and ORP anomalies were encountered at $14.408^{\circ} \mathrm{W}, 13.288^{\circ} \mathrm{S}$, directly beneath the plume maximum seen on 22II-L09 2 years earlier. The occurrence of maximum ORP and turbidity near $13.286^{\circ} \mathrm{S}$ indicates that active vents were present $\sim 700 \mathrm{~m}$ south of the known vent field (Fig. 5b).

\section{Temperature anomalies}

Temperature anomalies are unequivocal indicators of a hydrothermal plume, but are far less useful than many other tracers. Maximum vent fluid temperatures exceed ambient seawater temperature by a factor of $\sim 10^{2}$, but since plume dilution in the non-buoyant layer is often a factor of $\sim 10^{4}$
Table 1 Cruise chronology in the study area

\begin{tabular}{|c|c|c|c|}
\hline Cruise and Leg & Ship & Date & Segment \\
\hline The 4th leg of Chinese 21st Cruise (21IV) & DayangYiHao & Nov.-Dec. 2009 & The MAR $13^{\circ}-15^{\circ} \mathrm{S}$ \\
\hline The 2nd leg of Chinese 22nd Cruise (22II) & DayangYiHao & Jan.-Feb. 2011 & The MAR $13^{\circ}-14^{\circ} \mathrm{S}$ \\
\hline
\end{tabular}




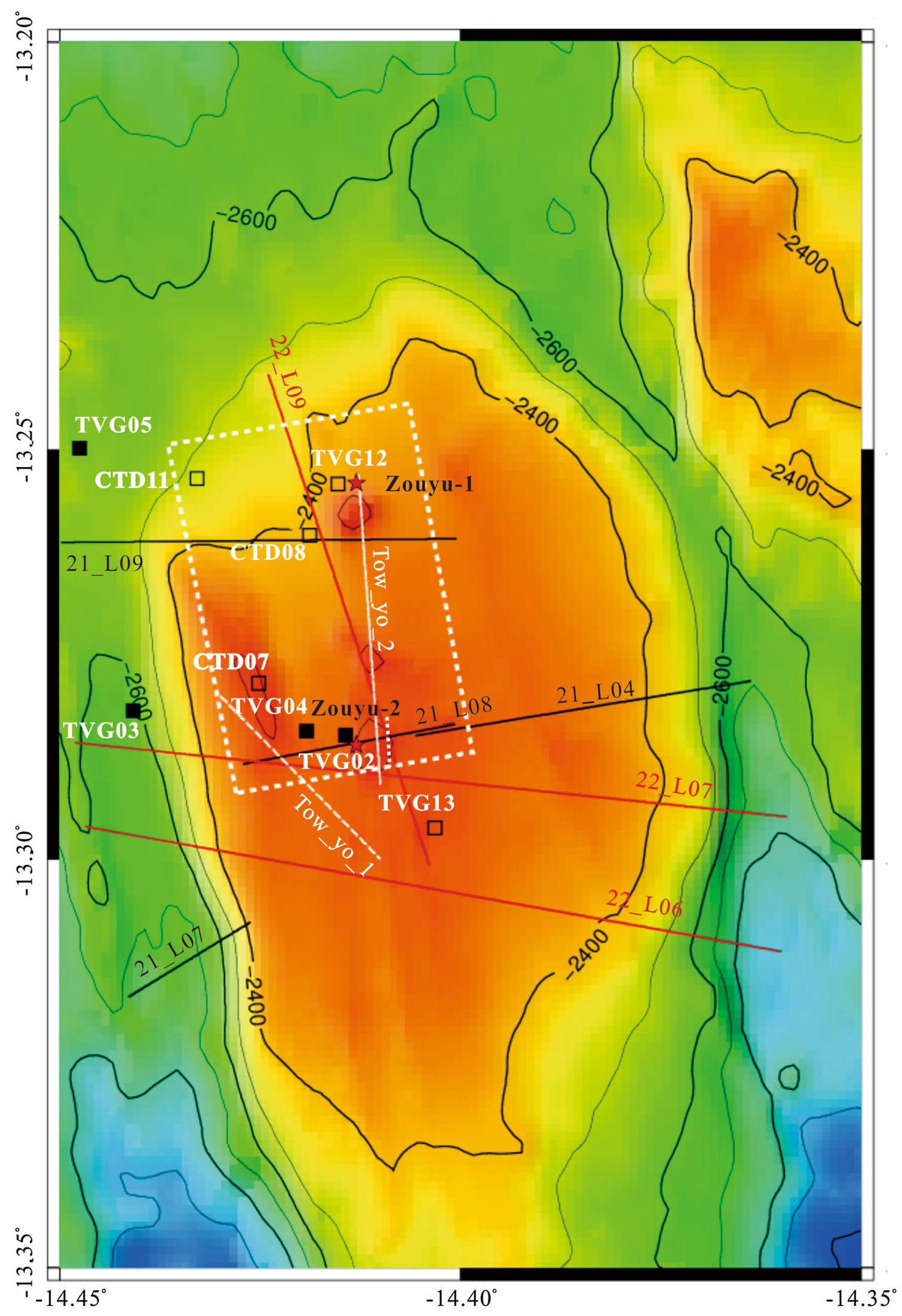




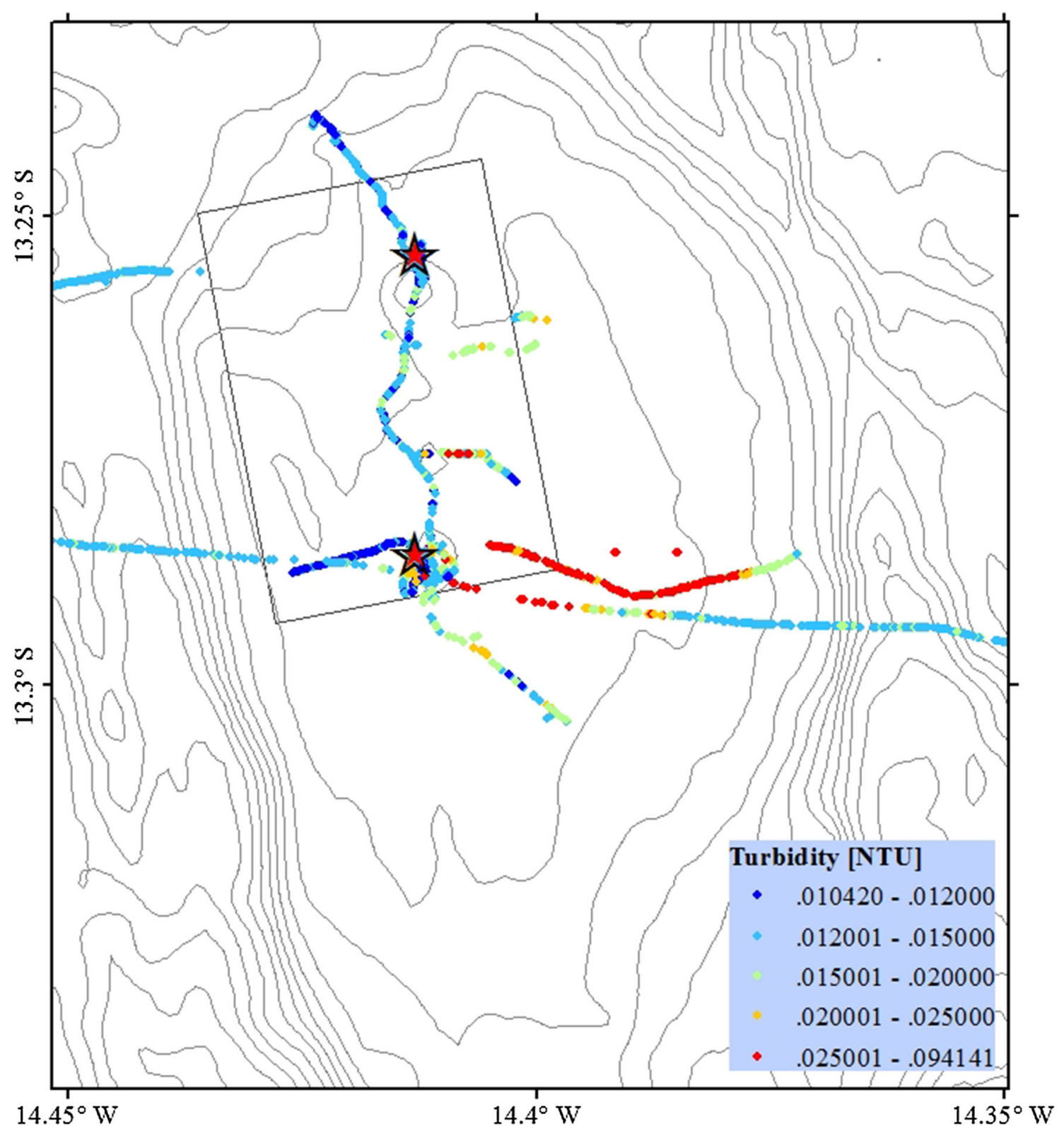

Fig. 4 Scatter plot of turbidity anomalies at depths $>2000 \mathrm{~m}$ using the data from Chinese 21st and 22nd cruises

detecting a hydrothermal temperature anomaly is difficult. This problem is magnified in the Atlantic, where the salinity gradient is negative and the non-buoyant plume is cooler and fresher than the surrounding seawater (Speer and Rona 1989). Vent locations can be precisely determined if a CTD intercepts a rising buoyant plume, before maximum dilution has occurred, but such occurrences are rare.

An example of the influence of a hydrothermal plume on the local water temperature can be seen from a MAPR tow near Zouyu-2 (Fig. 8). In the absence of salinity measurements temperature anomalies can be detected only by changes in raw temperature, rather than calculating an accurate temperature anomaly (e.g., Lupton et al. 1985). In this example, temperature along the track line increased by as much as $\sim 0.03{ }^{\circ} \mathrm{C}$ even as the depth of the MAPR was largely unchanged (vertical movements would strongly affect the observed temperature even in ambient water). The temperature fluctuations tracked concomitant fluctuations in turbidity, strong evidence that the temperature increases were hydrothermally induced.

\section{Using hydrothermal plume tracers for efficient vent and sulfide deposit exploration}

Exploring for sulfide deposits on the seafloor is fundamentally different than terrestrial exploration. On the seafloor, deposits are cloaked by an ocean that is opaque to 

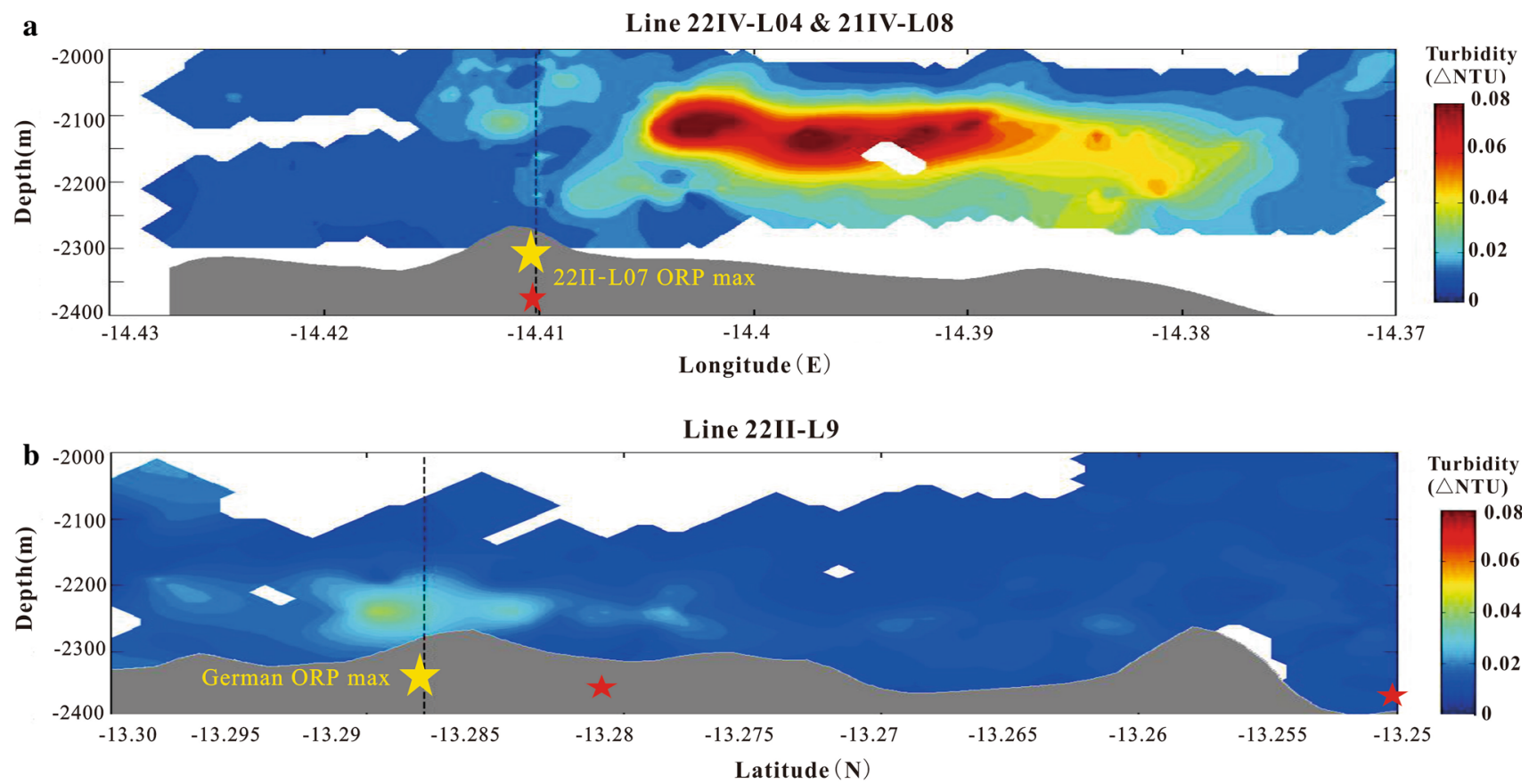

Fig. 5 Transects of turbidity and ORP from survey lines spanning 2009 to 2011. a 21IV-L04/21IV-L08 and b 22II-L09. Red stars show the vent location found by Chinese 21 st cruise, while bigger yellow stars show the location inferred from the maximum ORP during
MSM25 tow-yo lines (Devey 2014) and Chinese 22II-L07 survey line. Black dashed lines shows where Line 21IV-L04/L08 and Line 22II-L09 intersected electromagnetic inspection at distances of more than several meters. To efficiently locate these deposits we must use the clues provided by the plumes emitted by vents and dispersed by local currents. In this section we use our results from surveys of the Zouyu-1 and Zouyu-2 hydrothermal fields, in combination with knowledge about additional plume tracers, to describe how a broad tracer suite can be used to close range on seafloor polymetallic sulfides that occur in association with active venting.

Hydrothermal species can be classified as conservative or non-conservative. Conservative species include heat and ${ }^{3} \mathrm{He}$, and their concentration in plumes changes only by dilution. Non-conservative species, such as $\mathrm{Mn}, \mathrm{Fe}, \mathrm{CH}_{4}$, $\mathrm{H}_{2}$, and $\mathrm{H}_{2} \mathrm{~S}$ are also lost by chemical and biological degradation, or by deposition. Their residence time in the plume varies widely, from several years for dissolved $\mathrm{Mn}$ and Fe- and Mn-oxyhydroxides (Resing et al. 2015), to days or months for $\mathrm{CH}_{4}$ (Charlou and Donvald 1993), and to hours or days for $\mathrm{FeS}, \mathrm{H}_{2}, \mathrm{H}_{2} \mathrm{~S}$, and dissolved $\mathrm{Fe}^{+2}$ (Lilley et al. 1995). These differences in residence time make it possible to use a broad suite of tracer samples to efficiently close range on the seafloor sources that create plumes in a given section of a ridge (Fig. 9). The presence or absence of certain tracers also provides important clues to the temperature and chemistry of a source.

In this section we use our plume results and known vent field locations to calibrate a vent field search protocol.
Although we lack plume chemistry samples, we describe how such samples would improve our protocol when surveying a MAR site such as segment 14 .

The most sensitive hydrothermal tracer is ${ }^{3} \mathrm{He}$, and a single cast in a deep axial valley of the MAR can likely determine if hydrothermal vent sites are active. However, this sensitivity, combined with the present inability to analyze ${ }^{3} \mathrm{He}$ at sea, limits it usefulness as a search tool. More effective segment-scale tracers are $\mathrm{dMn}$ and $\mathrm{dFe}$ org. For example, $\mathrm{dFe}_{\text {org }}$, dissolved $\mathrm{Fe}$ stabilized against precipitation by organic compounds (Sander and Koschinsky 2011), can persist in plumes for thousands of kilometers (Saito et al. 2013; Resing et al. 2015). No real-time, precise detection of $\mathrm{dMn}$ or $\mathrm{dFe}_{\text {org }}$ is yet widely available, so discrete sampling is required. Suspended particles, which are closely related to turbidity anomalies, can also be useful hydrothermal species.

At smaller spatial scales, on the order of $10 \mathrm{~km}, \mathrm{CH}_{4}$ becomes an important tracer. $\mathrm{CH}_{4}$ is not present in all hydrothermal plumes, and some plumes from low-temperature discharge may have $\mathrm{CH}_{4}$ but no particles or metals (Charlou and Donvald 1993). For example, a survey of the slow-spreading Central Indian Ridge found a $\mathrm{CH}_{4}$ plume traceable for $\sim 10 \mathrm{~km}$ in one direction along axis but $<5 \mathrm{~km}$ in the opposite direction (You et al. 2014). Similar to ${ }^{3} \mathrm{He}$, sampling restrictions also limit the usefulness of $\mathrm{CH}_{4}$ for real-time exploration. Although $\mathrm{CH}_{4}$ is readily 

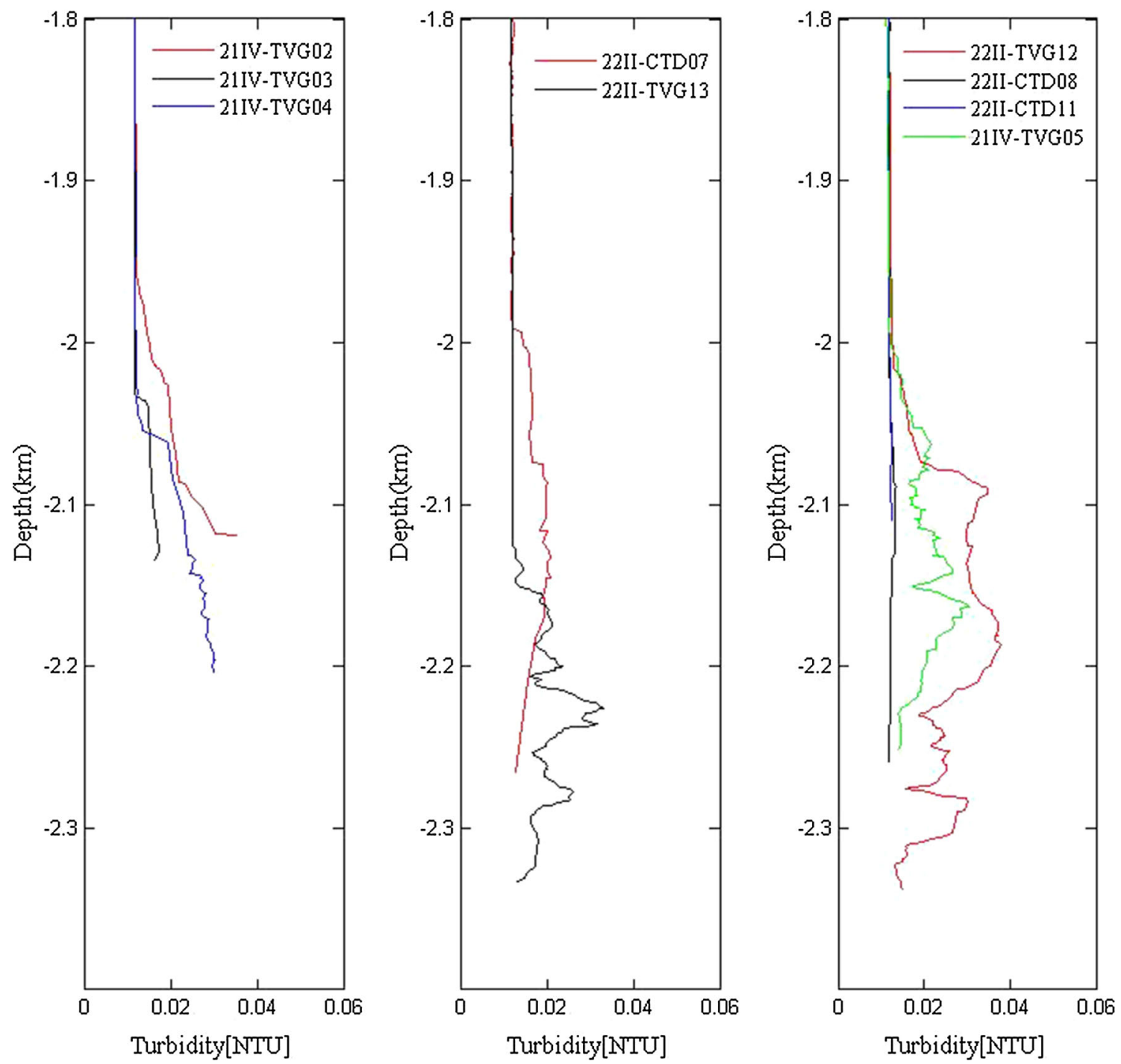

Fig. 6 Turbidity profiles in the Zouyu-1 and -2 hydrothermal fields. Different line colors represent different stations or lines

measured at sea from water samples, there is as yet no sensor that can confidently measure typical hydrothermal plume concentrations $(<\sim 50 \mathrm{nmol})$ in real time at plume depths.

Presently, real-time, continuous measurements of plume tracers are restricted to turbidity (light scattering and transmission), ORP (including $\mathrm{H}_{2} \mathrm{~S}$ (ECS)), and temperature. Turbidity measurements are by far the most commonly used tool for plume mapping. Turbidity anomalies have been traced up to $100 \mathrm{~s}$ of $\mathrm{km}$ along a ridge axis, testifying to the long residence time of fine-grained Feoxyhydroxide particles $\left(\mathrm{pFe}_{\text {oxy }}\right)$ (Baker and German 2004). Here, however, we look at the ability of turbidity data to precisely locate a vent source. Two survey lines passed close to the Zouyu-2 field: 21IV-L04\&L08 in Nov. 2009 and 22II-L09 in Feb. 2011. On each line, turbidity anomalies described a plume with a lateral dimension of
3-5 km, with a maximum plume anomaly near the Zouyu2 field (Fig. 5), which is thus the effective vent field location precision when using only turbidity signals.

Certain chemical tracers are capable of even greater precision because they are rapidly oxidized, metabolized, or chemically transformed within hours or days. These include various sulfide species ( $\mathrm{such}$ as $\mathrm{HS}^{-}$), $\mathrm{Fe}^{2+}$, and $\mathrm{H}_{2}$. Each of these reduced species produces a pronounced ORP response (Sudarikov and Roumiantsev 2000; German et al. 2008; Stranne et al. 2010; Baker et al. in press). Because these chemicals dissipate quickly, they can be detected only very close to their source. Baker et al. (in press) quantified the spatial scale of such anomalies by measuring the path length of 290 ORP anomalies during instrument tows along four different ridge sections. The mean path length was $0.57 \pm 0.72 \mathrm{~km}$ (median value $=0.30 \mathrm{~km})$, suggesting a nominal precision in 


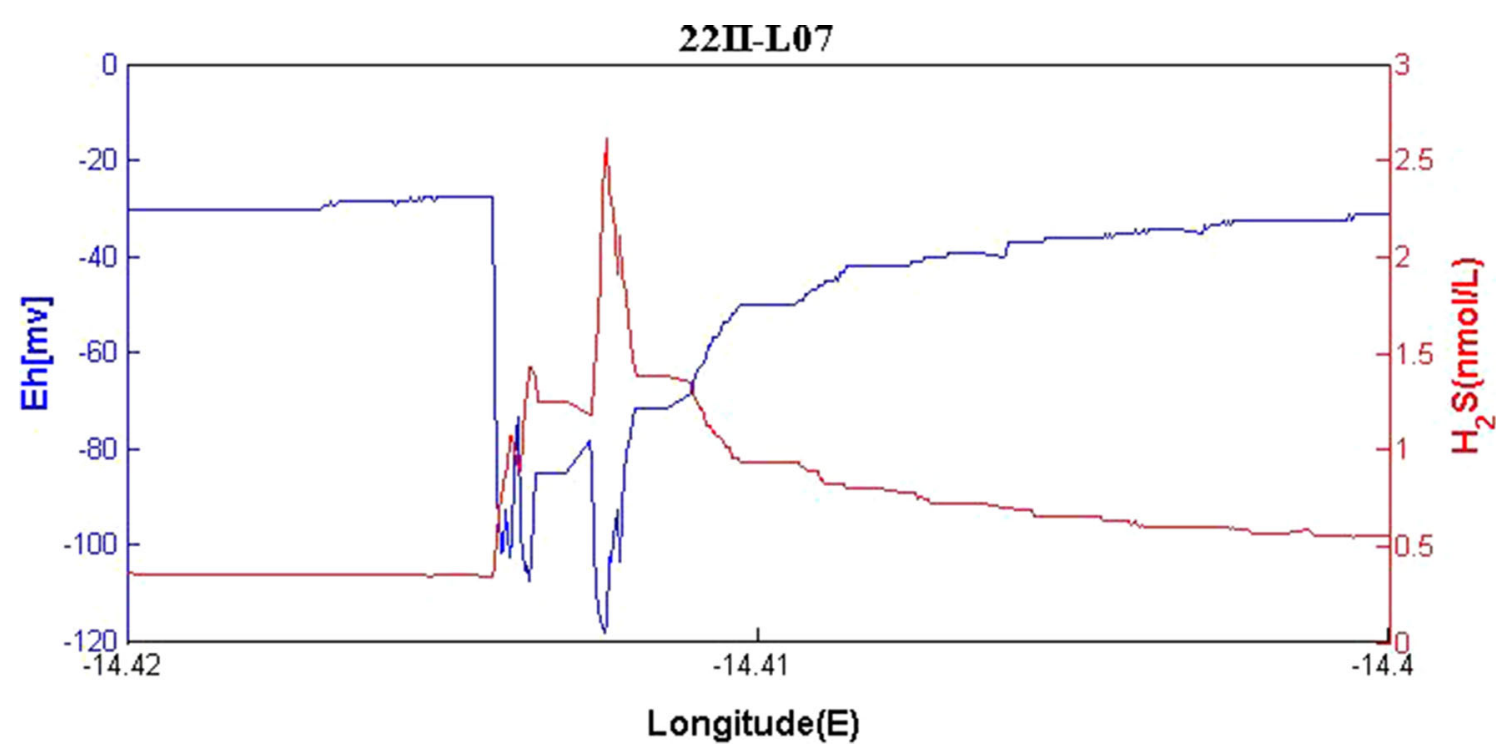

Fig. $7 \mathrm{ORP}$ and $\mathrm{H}_{2} \mathrm{~S}$ anomalies on the 22II-L07 survey line (see Fig. 5)

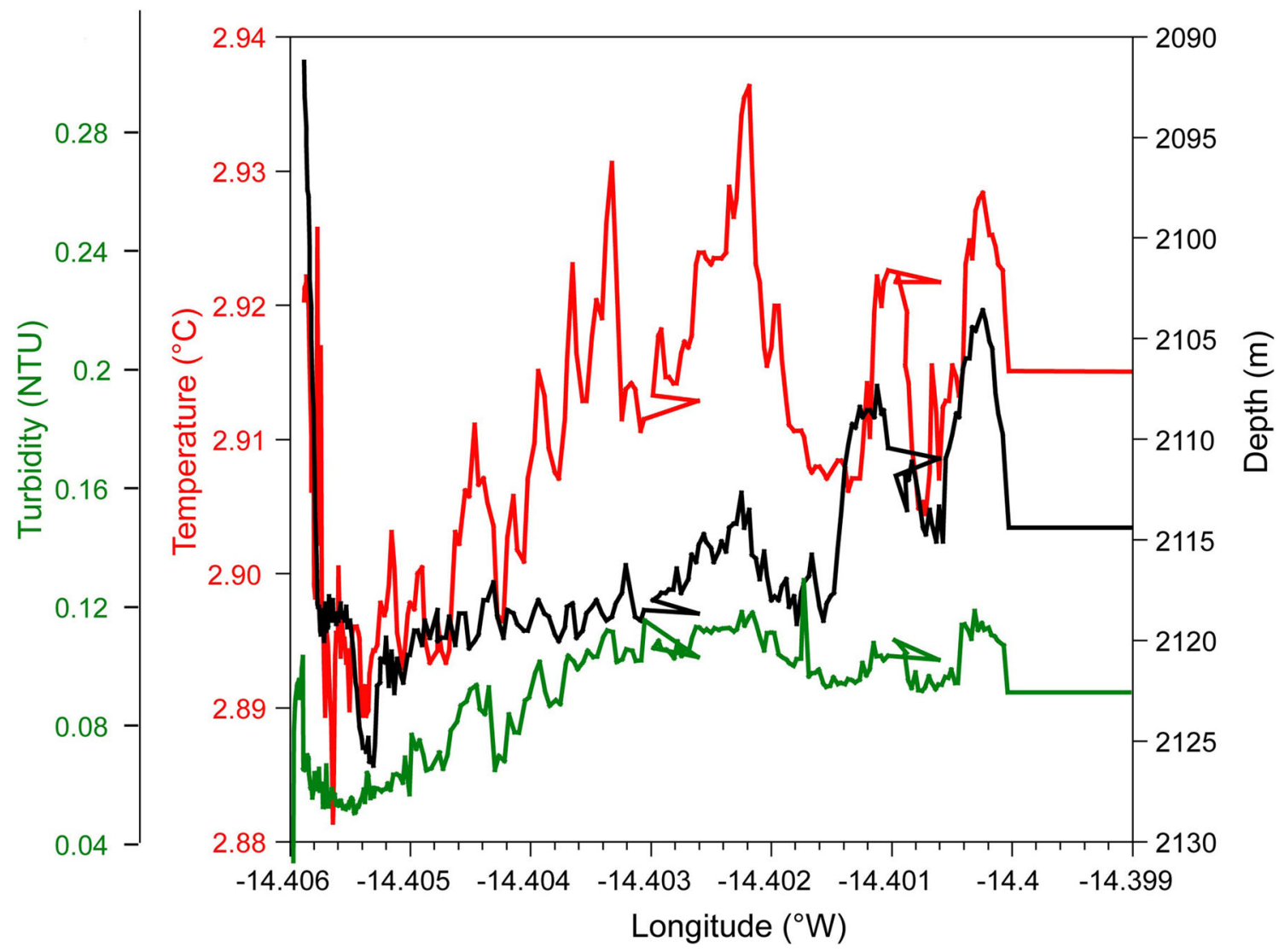

Fig. 8 In situ temperature (red line), turbidity (green line), and depth (black line) from a MAPR at an altitude of $\sim 200 \mathrm{~m}$ during Line 21IV-L04 (see Fig. 5a)

source location of $<1 \mathrm{~km}$. This estimate is a conservative one, because the source is likely closest to the location of maximum ORP response, which normally occurs over a spatial scale of $100 \mathrm{~s}$ of meters or less (Fig. 7). The distance between known location of Zouyu- 2 and the ORP max anomaly seen in Fig. $7 \mathrm{a}$ is $\sim 0.1-0.2 \mathrm{~km}$. 


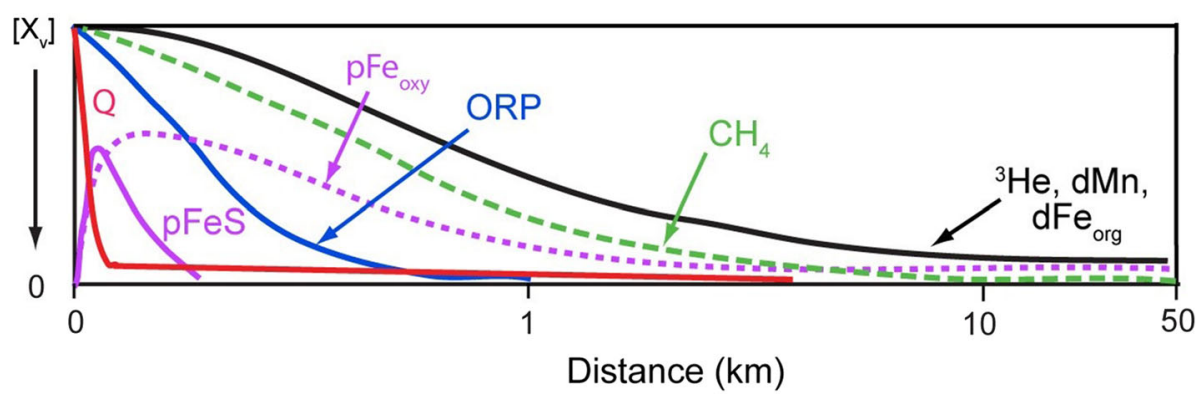

Fig. 9 An idealized comparison of how detectable plume chemistry can change over distance. Distances are qualitative and depend on source strength, current flow, and bathymetry. These changes mean that different tracers provide different information about the range to an active vent site. Each curve shows the change in the relative concentration of a tracer from a vent orifice $\left(X_{\mathrm{v}}\right)$ to a nominal $50 \mathrm{~km}$ distance. "ORP" refers to dissolved reduced substances such as $\mathrm{H}_{2}$, $\mathrm{H}_{2} \mathrm{~S}$, and $\mathrm{Fe}^{+2}$. All other tracers are dissolved species except $\mathrm{FeS}$ and

\section{Conclusions}

We analyzed hydrothermal plume data from around the Zouyu Ridge on the southern MAR using deep-tow survey lines and vertical profiles from 2009 and 2011 to map turbidity, ORP, and temperature anomalies. The plume from the Zouyu-2 field was prominent, with a turbidity maximum (NTU $>\sim 0.04$ ) typically detectable $>3 \mathrm{~km}$ from the source. Sidescan sonar and video confirmed that the area was covered by fresh lava, related to hydrothermal eruptions. Plumes from the Zouyu-1 field were less robust and more difficult to detect farther than $\sim 1 \mathrm{~km}$ from the source. Data from 2011 found the Zouyu-2 plume to have the lowest NTU values and a rise height $\sim 100 \mathrm{~m}$ less than in 2009, suggesting a temporary decrease in vent field buoyancy flux at that time.

We used these data to evaluate the use of various tracers for locating active vent sites, and thus possible adjoining inactive sulfide deposits. Turbidity is the best real-time sensor for detecting active sites at ranges of $\sim 10 \mathrm{~km}$ or more. At spatial scales of $<\sim 3 \mathrm{~km}$ the quasi-conservative nature of fine particles, combined with current fluctuations, limits its usefulness in identifying a source location. Temperature and ORP are not useful tracers at scales $>$ a few kilometers, but are highly precise (a few hundred meters) at smaller scales. However, temperature anomalies are generally weak and variable. Real-time exploration with a combination of turbidity and ORP sensors is most effective.

Acknowledgments This work was supported by National Basic Research Program of China (973 Program) under contract No. 2012CB417305, China Ocean Mineral Resources R \& D Association "Twelfth Five-Year" Major Program under contract No. DY125-11R-01 and DY125-11-R-05, and Zhejiang Provincial Natural Science Foundation of China under Grant No. Q16D060018. Support for ETB
$\mathrm{Fe}_{\text {oxy }}$ (Fe oxyhydroxides), which precipitate from dissolved species as vent fluids are diluted. About half the particulate $\mathrm{Fe}$ is deposited close to the vent as sulfides, while the other half more slowly precipitates and settles as fine-grained $\mathrm{Fe}_{\text {oxy }}$. $\mathrm{dMn}$ precipitates and settles slowly, similar to $\mathrm{dFe}_{\text {org. }}$. Only ${ }^{3} \mathrm{He}$ and heat $(\mathrm{Q})$ are truly conservative, but heat anomalies are diluted beyond detection within a few kilometers of a vent source

was provided by the NOAA/PMEL Earth-Ocean Interactions Program and the Joint Institute for the Study of the Atmosphere and Ocean (JISAO) under NOAA Cooperative Agreement No. NA10OAR4320148. We thank the science parties of DY21 and DY22, who contributed to the success of the project. PMEL contribution 4486, JISAO contribution 2654.

Open Access This article is distributed under the terms of the Creative Commons Attribution 4.0 International License (http://creative commons.org/licenses/by/4.0/), which permits unrestricted use, distribution, and reproduction in any medium, provided you give appropriate credit to the original author(s) and the source, provide a link to the Creative Commons license, and indicate if changes were made.

\section{References}

Baker ET (1994) A six-year time series of hydrothermal plumes over the Cleft segment of the Juan de Fuca Ridge. J Geophys Res 99:4889-4904

Baker ET, German CR (2004) On the global distribution of hydrothermal vent fields. In: German CR (ed) Mid-Ocean Ridges: hydrothermal interactions between the lithosphere and oceans. Geophys Monogr Ser Vol 148, AGU, Washington DC, pp 245-266

Baker ET, German CR, Elderfield H (1995) Hydrothermal plumes over spreading-center axes: Global distributions and geological inferences. In: Humphris S (ed) Seafloor hydrothermal systems: physical, chemical, biological, and geological interactions, Geophys Monogr Ser, vol 91. AGU, Washington DC, pp 47-71

Baker ET, Resing JA, Haymon RM, Tunnicliffe V, William Lavelle J, Martinez F, Ferrini V, Walker SL, Nakamura K (in press) How many vent fields? New estimates of vent field populations on ocean ridges from precise mapping of hydrothermal discharge locations. Earth Planet Sci Lett

Beaulieu SE, Baker ET, German CR (2015) Where are the undiscovered hydrothermal vents on oceanic spreading ridges? Deep Sea Res Part II. doi:10.1016/j.dsr2.2015.05.001i

Charlou J-L, Donvald J-P (1993) Hydrothermal methane venting between $12^{\circ} \mathrm{N}$ and $26^{\circ} \mathrm{N}$ along the Mid-Atlantic Ridge. J Geophys Res 98:9625-9642

Charlou JL, Dmitriev L, Bougault H, Needham HD (1988) Hydrothermal $\mathrm{CH}_{4}$ between $12^{\circ} \mathrm{N}$ and $15^{\circ} \mathrm{N}$ over the MidAtlantic Ridge. Deep Sea Res Part I 35:121-131 
Chen S, Tao C, Li H, Chen Y, Zhou J, Wu T (2014) A data processing method for MAPR hydrothermal plume turbidity data and its application in the Precious Stone Mountain hydrothermal field. Acta Oceanol Sin 33:34-43

DeMets C, Gordon R, Argus D, Stein S (1994) Effect of recent revisions to the geomagnetic reversal time scale on estimates of current plate motions. Geophys Res Lett 21:2191-2194

Devey CW (2014) SoMARTherm: The Mid-Atlantic Ridge $13-33^{\circ} \mathrm{S}-$ Cruise No. MSM25-January 24-March 5, 2013-Cape Town (South Africa)-Mindelo (Cape Verde). Bremen. doi:10.2312/cr msm25

Devey CW, Lackschewitz K, Baker E (2005) Hydrothermal and volcanic activity found on the Southern Mid-Atlantic Ridge. Trans Eos American Geophys Union 86:209-212

Devey CW, German C, Haase K, Lackschewitz K, Melchert B, Connelly D (2010) The relationships between volcanism, tectonism, and hydrothermal activity on the southern equatorial Mid-Atlantic Ridge. In: Rona PA, Devey CW, Dyment J, Murton B (eds) Diversity of hydrothermal systems on slow spreading ocean ridges, Geophys Monogr Ser, vol 188. AGU, Washington DC, pp 133-152

Fang J, Sun J, Xu H, Ye J, Chen J, Ren M, Tang C (2015) Prediction of seafloors polymetallic sulphides resources in the north Atlantic ridge area. Adv Earth Sci 30:60-68 (in Chinese)

German CR, Klinkhammer GP, Rudnicki MD (1996) The Rainbow hydrothermal plume, $3615^{\prime} \mathrm{N}$, MAR. Geophys Res Lett 23:2979-2982

German CR et al (2008) Hydrothermal activity on the southern MidAtlantic Ridge: tectonically- and volcanically-controlled venting at 4-5 S. Earth Planet Sci Lett 273:332-344

German CR, Petersen S, Hannington MD (2016) Hydrothermal exploration of mid-ocean ridges: where might the largest sulfide deposits be forming? Chem Geol 420:114-126

Haase KM et al (2007) Young volcanism and related hydrothermal activity at $5 \mathrm{~S}$ on the slow-spreading southern Mid-Atlantic Ridge. Geochem Geophys Geosyst. doi:10.1029/2006GC001509

Haase KM et al (2009) Diking, young volcanism and diffuse hydrothermal activity on the southern Mid-Atlantic Ridge: the Lilliput field at $933^{\prime}$ S. Mar Geol 266:52-64

Haase K et al (2012) Compositional variation of lavas from a young volcanic field on the Southern Mid-Atlantic Ridge, $8^{\circ} 48^{\prime} \mathrm{S}$. American Geophysical Union, Fall Meeting 2012, Abstract \#V11D-2806

Han C, Wu G, Ye Y, Qin H (2015) Active hydrothermal and non-active massive sulfide mound investigation using a new multi-parameter chemical sensor. In: Kennis C (ed) Testing and measurement: techniques and applications. Proceedings of the 2015 international conference on testing and measurement: techniques and applications (TMTA 2015), Phuket Island, pp 183-186

Hannington M, Jamieson H, Monecke T, Petersen S, Beaulieu S (2011) The abundance of seafloor massive sulfide deposits. Geology 39(12):1155-1158

Keir RS, Schmale O, Walter M, Sültenfuß J, Seifert R, Rhein M (2008) Flux and dispersion of gases from the "Drachenschlund" hydrothermal vent at $818^{\prime} \mathrm{S}, 1330^{\prime} \mathrm{W}$ on the Mid-Atlantic Ridge. Earth Planet Sci Lett 270(3):338-348

Krasnov et al (1995) Detailed geographical studies of hydrothermal fields in the North Atlantic. Geol Soc Lond Spec Publ 87(1):43-64

Langmuir C et al (1997) Hydrothermal vents near a mantle hot spot: the Lucky Strike vent field at $37 \mathrm{~N}$ on the Mid-Atlantic Ridge. Earth Plan Sci Lett 148(1):69-91

Lilley MD, Feely RA, Trefry JH (1995) Chemical and biological transformations in hydrothermal plumes, In: Humphris $\mathrm{S}$, Zierenberg R, Mullineaux LS, Thomson R (eds) Seafloor hydrothermal systems: physical, chemical, biological, and geological interactions, Geophys Monog Ser, vol 91, AGU, Washington DC, pp 369-391

Lupton JE, Craig H (1981) A major helium-3 source at $15 \mathrm{~S}$ on the East Pacific Rise. Science 214:13-18

Lupton E et al (1985) Entrainment and vertical transport of deepocean water by buoyant hydrothermal plumes. Nature 316:621-623

Macdonald K (2001) Mid-ocean ridge tectonics, volcanism and geomorphology. In: Encyclopedia of Ocean Sciences, pp 1798-1813

Melchert B, Devey CW, German CR, Haase KM, Koschinsky A, Lacksschewitz K, Yoerger D (2006) Volcanic and tectonic setting of hydrothermal activity on the Southern Mid-Atlantic Ridge, $4^{\circ}-11^{\circ} \mathrm{S}$. American Geophysical Union, Fall Meeting 2006

Melchert B et al (2008) First evidence for high-temperature off-axis venting of deep crustal/mantle heat: the Nibelungen hydrothermal field, southern Mid-Atlantic Ridge. Earth Planet Sci Lett 275:61-69. doi:10.1016/j.eps1.2008.08.010

Mottl MJ, McConachy TF (1990) Chemical processes in buoyant hydrothermal plumes on the East Pacific Rise near $21^{\circ} \mathrm{N}$. Geochim Cosmochim Acta 54:1911-1927

Murton BJ et al (1994) Direct evidence for the distribution and occurrence of hydrothermal activity between $27^{\circ} \mathrm{N}-30^{\circ} \mathrm{N}$ on the Mid-Atlantic Ridge. Earth Planet Sci Lett 125:119-128. doi:10. 1016/0012-821x(94)90210-0

Nautilus Minerals Inc. (2014) Annual Report. http://www.nautilus minerals.com

Resing JA, Sedwick PN, German CR, Jenkins WJ, Moffett JW, Sohst BM, Tagliabue A (2015) Basin-scale transport of hydrothermal dissolved metals across the South Pacific Ocean. Nature 523:200-203. doi:10.1038/nature 14577

Rona P, Klinkhammer G, Nelsen T, Trefry J, Elderfield H (1986) Black smokers, massive sulphides and vent biota at the MidAtlantic Ridge. Nature 321:33-37

Rona PA, Devey CW, Dyment J, Murton BJ (2010) Diversity of hydrothermal systems on slow spreading ocean ridges. Geophys Monogr Ser, vol 188. AGU, Washington

Rudnicki MD, Elderfield H (1992) Theory applied to the Mid-Atlantic ridge hydrothermal plumes: the finite-difference approach. J Volcanol Geotherm Res 50:161-172

Rudnicki MD, Germa CR (2002) Temporal variability of the hydrothermal plume above the Kairei vent field, $25^{\circ} \mathrm{S}$, Central Indian Ridge. Geochem Geophys Geosyst. doi:10.1029/ 2001GC000240

Ryan WBF et al (2009) Global multi-resolution topography synthesis. Geochem Geophys Geosyst. doi:10.1029/2008GC002332

Saito MA, Noble AE, Tagliabue A, Goepfert TJ, Lamborg CH, Jenkins WJ (2013) Slow-spreading submarine ridges in the South Atlantic as a significant oceanic iron source. Nat Geosci 6:775-779

Sander SG, Koschinsky A (2011) Metal flux from hydrothermal vents increased by organic complexation. Nat Geosci 4:145-150

Shao K, Chen J, Ren M (2015) Evaluation methodology and indicator system of polymetallic sulfide Mineral resources in the southwest Indian ocean. Adv Earth Sci 30:812-822 (in Chinese)

Smith WH, Sandwell DT (1997) Global sea floor topography from satellite altimetry and ship depth soundings. Science 277:1956-1962

Speer KG, Rona PA (1989) A model of an Atlantic and Pacific hydrothermal plume. J Geophys Res 94:6213-6220

Stranne C, Sohn RA, Liljebladh B, Ki Nakamura (2010) Analysis and modeling of hydrothermal plume data acquired from the $85 \mathrm{E}$ segment of the Gakkel Ridge. J Geophys Res: Oceans 115:C06028. doi:10.1029/2009JC005776

Sudarikov SM, Roumiantsev AB (2000) Structure of hydrothermal plumes at the Logatchev vent field, $1445^{\prime} \mathrm{N}$, Mid-Atlantic Ridge: 
evidence from geochemical and geophysical data. J Volcanol Geotherm Res 101:245-252

Tao C et al (2011) Two hydrothermal fields found on the Southern Mid-Atlantic Ridge. Sci China: Earth Sci 54:1302-1303

Tao C et al (2014) Seafloor hydrothermal activity and polymetallic sulfide exploration on the southwest Indian ridge. Chin Sci Bull 59:2266-2276. doi:10.1007/s11434-014-0182-0

Tivey MK (2007) Generation of seafloor hydrothermal vent fluids and associated mineral deposits. Oceanography 20:50-65
Yao H et al (2011) Integration studyon mode for seafloor plolymetallic sulfide exploration. J Central South Univ (Sci Technol) 42:114-122 (in Chinese)

You O-R, Son SK, Baker ET, Son J, Kim MJ, Barcelona MJ, Kim M (2014) Bathymetric influence on dissolved methane in hydrothermal plumes revealed by concentration and stable carbon isotope measurements at newly discovered venting sites on the Central Indian Ridge (11-13 ${ }^{\circ}$ S). Deep Sea Res Part I 91:17-26. doi:10.1016/j.dsr.2014.05.011 